\title{
Blinded by science: The social implications of epigenetics and neuroscience
}

\author{
David Wastell and Susan White, 2017 \\ Policy Press, Bristol UK \\ ISBN 978-1-4473-2234-4, pp. 299, pp. NZD44.00
}

$\mathrm{T}$ The aim of this important book is to develop a much wider understanding of how the new biologies of neuroscience and epigenetics are being invoked in the current welfare discourse in western countries. The back-cover blurb presents the focus in simple terms: the book "draws attention to the ways that the uncertainties of the original science are lost in their translation into the everyday world of practice and policy." Space in a review does not allow for a detailed summary of the detailed and complex scholarship in this book so I will focus on some core aspects and hopefully encourage readers to read it for themselves. The publishers have helpfully made this book available in several different formats.

I was very pleased to see the publication of Blinded by Science after following the authors' scholarship on this topic for several years (Wastell, White, \& Lorek, 2013; White \& Wastell, 2015). Like many social workers, I had been influenced by the hype of "the brains" by attending a public lecture (see Beddoe, 2017 for my blog post on this experience). It was some years later that the work of Susan White, a professor of social work at the University of Sheffield and David Wastell, a cognitive neuroscientist, now emeritus professor at the University of Nottingham, introduced me to the rapidly developing critique of the unquestioning acceptance of neuroscience in social policy. As always, social policy influences what happens in social work as policy is distilled down to procedure, then practice. But social policy doesn't emerge from a neutral "laboratory" where ideology-free experts develop scientific interventions to treat social problems. It seems to me that there is a complex set of circular processes where ideological trends (discourses) reflect and maintain policy makers' inclinations, the science is then applied to create evidence that then confirms the beliefs of the policy makers (or policy-led evidence). But the powerful will insist that it's the science that tells them what should be done. Wastell and White quote from Khan (2010, p. 311):

Science is not an anthropomorphic being, it does not "tell" anything. Scientific data has no meaning until one interprets it and such interpretations are inevitably packed with qualitative judgements.

Essentially, the argument in the book is that the invocation of neuroscience and epigenetics in social policy is far from neutral and is following a trend that began in the 20th century with the intensification of both the public and state gaze on parenting, particularly in early childhood. If one follows the presentation of childhood in public discourse over the last seven decades or so, children are increasing characterised as vulnerable and in constant need of state surveillance. In the risk society (Beck, 1992), children are fragile entities to be micromanaged by newly intensified parental citizens, charged with ensuring that little Timothy and Amanda grow up to be productive and avoid becoming a costly drain on the taxpayer.

Wastell and White begin this book with a very useful overview of the links between biology and the drive for "human improvement." 
They assert that this is not an ideologically neutral trend because, "Rather than challenging orthodoxies, both neuroscience and epigenetics are presently being co-opted to support old moral arguments" (p. 7). These moral arguments are ancient-the comforting ethos of capitalist conservatism - that the poor have moral deficits and are poor because of these, rather than because of the greed and corruption of the rich. So it is inevitable that the development of persuasive new science can be harnessed to the ideological project of welfare cuts and micro-targeting the deprived and disadvantaged with programmes designed to fix them. The focus is firmly fixed on individuals and families, rather than structural problems: "Prevention and targeting are prominent motifs in an increasingly residual and conditional welfare settlement, providing a natural slot for technologies which can tease out individual susceptibilities" (p. 7).

The second chapter of the book provides a very good overview of how knowledge is made. The authors make a distinction between "journal science" which is often couched carefully as tentative, requiring further testing; and "handbook science" where knowledge is codified and simplified for consumption by those closer to the target population: practitioners, who lack the time (and, it is assumed, expertise?) to interrogate the research that is said to underpin the interventions the lean state will pay for. In addition, the authors point out much of the evidence is based on animal studies and the researchers themselves may caution generalisation or application to human populations.

The chapter "Blaming the brain" reviews various attempts, throughout history, to find biological explanations of mental illness and, in particular, examines the current focus on genetic explanations of autism and ADHD. The authors simply infer from their review that in spite of recent research few "killer insights" have emerged (p. 89).

Part two of the book shifts our focus to policy. Its stated aim is to explore the impact of the explosion of brain science in mainstream government policy. Early intervention, they argue, is driven by a myth that the impairment of the infant brain is responsible for "madness, badness and all manner of vexing social problems" (p. 89), even poverty itself.

This chapter takes the reader carefully through the reverse journey from policy analysis to evidence to practice. These sentences succinctly summarise their review:

Finding evidence for policy can be something of a fishing expedition. Persuasion, not accuracy is the primary criterion at work. The evidence has been interpreted as consistent with a particular form of received wisdom and hence little argumentation is required to make it work rhetorically. (p. 108)

After exploring the science behind many claims of the irreversibility of childhood neglect (with the lurid and misleading brain imagery I discussed in Beddoe (2017)), Wastell and White state that "science has been selectively used to grant epistemic authority to the cause of early intervention" (p. 108).

It is chapters 5 and 6 which form the section I would set as required reading for every social worker in children and families social work: it addresses the really sharp end of this particular stick. Where the early intervention policy based on poor reading of complex science hits child protection (see also Featherstone, Morris, \& White, 2013). Read these chapters if you read nothing else this year.

Wastell and White, using the example of strong state advocacy of early nonconsensual adoption in England and Wales, demonstrate the pernicious manipulation of policy by lobbyists for the "early years" brigade. Scraping away all of the jargon and scientism, the argument boils down to favouring a precautionary approach over a proportional approach. So, on the chance that less than optimal parenting (defined by whom?) might produce irreversible brain 
damage and welfare dependent criminals, we will go more quickly to permanent removal. The disproportionality is, of course, that the damage caused by very, very severe neglect has been observed in a vanishingly small number of extreme cases. Social policy is thus made by boosting tentative science and spinning it in conveniently palatable metaphors to persuade politicians (who, it has to be said, are often proud of saying "give me one page or I won't read it"), to support what is essentially a moral crusade.

Remove the child, just in case. Throw cash at programmes that focus on early years for those deemed at risk but never, ever look at trying to fix the pernicious effects of poverty, oppression and social exclusion.

As Wastell and White point out, the role of prevention science is to root out disease and dysfunction early. The effects of troublesome social problems like poverty, racism and other forms of social exclusion are recast as problems of dysfunctional parents who must be targeted for interventions or have their vulnerable children removed. Early intervention is politically popular as it seems innocuous and supportive. And of course, it can be if it is voluntary and collaborative, emphasising relationship building and planning with families at the forefront. But sadly, solutions tend to be topdown-imposed and such programmes may reconfigure relationships between the state and families (see, for example, McKendrick, 2016; Crossley, 2015).

In conclusion, this book provides a wealth of information and helpful analysis. There is much more that I could comment on but I would strongly recommend that readers buy this book and share with colleagues. I will finish with an interesting note on an issue of great relevance to social workers in Aotearoa New Zealand. Wastell and White make reference to family group conferences, acknowledging their birthplace here in
Aotearoa. Having mentioned the variable impacts in the international arena and the challenges of evaluating them, they conclude with this question:

What happens then if we stop treating FGCs as interventions in need of evaluation to judge their efficacy and cost-effectiveness? What happens if we treat them instead as the democratic right of citizens-which is indeed the case in New Zealand? (p. 147)

Imagine if we had policy makers who would listen to research that has found no evidence for the claims made by those with vested interests, for example about lazy, drugaddled kiwi workers or "multigenerational worklessness." Imagine if critical social policy studies and poverty research were used to influence governments. There would be no justification for not immediately instigating a universal basic income.

\section{References}

Beck, U. (1992). Risk society: Towards a new modernity. London, UK: Sage.

Beddoe, L. (2017, January 4). Brains, biology and tests for future burdenhood [Web log post]. Retrieved from http://www.reimaginingsocialwork.nz/2017/01/brainsbiology-and-tests-for-future-burdenhood-misguidedblind-faith-in-science/

Crossley, S. (2015). Realising the (troubled) family: Crafting the neoliberal state. Families, Relationships and Societies, 5(2), 263-279. doi:http://dx.doi.org/10.1332/ $204674315 X 14326465757666$

Featherstone, B., Morris, K., \& White, S. (2013). A marriage made in hell: Early intervention meets child protection. British Journal of Social Work. doi:10.1093/bjsw/bct052

Khan, F. (2010). Preserving human potential as freedom: A framework for regulating epigenetic harms. Health Matrix: Journal of Law-Medicine, 20(2), 259-323.

McKendrick, D. (2016). Crafting the society of control: Exploring Scottish child welfare policy in a neoliberal context. Aotearoa New Zealand Social Work, 28(3), 37-46. doi:http://dx.doi.org/10.11157/anzswj-vol28iss3id242

Wastell, D., White, S., \& Lorek, A. (2013). The child's timeframe: A neuro scientific perspective. London UK: 14 Gray's Inn Square

White, S., \& Wastell, D. (2015). The rise and rise of prevention science in UK family welfare: Surveillance gets under the skin. Families, Relationships and Societies. doi:http://dx.doi.org/10.1332/20467431 5X14479283041843 